\title{
Predicting Economic Activity In Serbia By Constructing Serbian Leading Economic Indicator (SERLEI)
}

\author{
Article history \\ Received: 17 June 2013 \\ Sent for revision: 21 June 2013 \\ Received in revised form: 09 July 2013 \\ Accepted: 10 July 2013 \\ Available online: 11 July 2013
}

Abstract: Timely identification of the next stage of business cycle, or a shift in economic activity from the previous trend, is a critical factor for the success of counter-cyclical economic policy. This paper is based on the construction of a new leading indicator of the business cycle which, with a certain time lag, suggests the next stage of the business cycle in the Republic of Serbia. SERLEI (Serbian Leading Economic Indicator) is tested in the period of expansion and at the beginning of recession in the Serbian economy to show to what extent it was possible to predict a shift in business cycles.

Key words: Business Cycle, Economic indicator, Time Lag, Markov RegimeSwitching Model

\section{Predviđanje privredne aktivnosti u Srbiji primenom SERLEI indikatora}

Apstrakt: Blagovremena identifikacija naredne faze privrednog ciklusa, odnosno zaokreta u privrednoj aktivnosti u odnosu na prethodni trend, predstavlja kritičan faktor za uspeh kontraciklične ekonomske poltike. U osnovi rada je konstruisanje novog vodećeg indikatora privrednog ciklusa koji uz određeni vremenski pomak nagoveštava sledeću fazu privrednog ciklusa u Republici Srbiji (SERLEI - Serbian leading economic indicator). SERLEI je

\footnotetext{
${ }^{1}$ University Union, Belgrade Banking Academy, Faculty for Banking, Insurance and Finance, sandra.kamenkovic@bba.edu.rs

2 University Union, Belgrade Banking Academy, Faculty for Banking, Insurance and Finance, zoran.grubisic@bba.edu.rs
} 
Kamenković S. et al.: Predicting Economic Activity In Serbia By Constructing...

testiran u periodu ekspanzije i ulaska privrede Srbije u recesiju da pokaže $u$ kojoj meri je bilo moguće najaviti zaokret u privrednim ciklusima

Ključne reči: poslovni ciklusi, ekonomski indikatori, Vreme kašnjenja , Markov režim - Svitčing model

\section{Introduction and a short literature review}

History shows that interest in business cycles is subject to fluctuations, just as much as the economic trends - it grows in times of economic turbulence, especially the economic crisis and recession, and declines in periods of stability and continuous economic growth. Despite the fact that the issue of business cycles is an important one in economic theory, there is still no common agreement on what causes contraction of economic activity and yet there is no solution to this problem. The most detailed and most accurate historical record of business cycles is considered to be the one published by the National Bureau of Economic Research (NBER), the American Committee for business cycle, made up of a group of important, but independent economists. Until the outburst of the current crisis, the indicators showing the duration of individual phases of the business cycle, as well as the characteristics of economic contractions, suggested that there was a prolonged stage of expansion and shortened stage of contraction as well as the smoothening of its severity (Praščević, 2009).

Timely identification of business cycles, that is identification of economic activity stages in which there is a shift from the previous trend, is a key factor for the successful implementation of counter-cyclical measures of the economic policy. In spite of the importance that this issue has in both academic research and practice, in many countries there were no serious attempts to develop methodology for the construction of aggregate indicator that would indicate the shift in the business cycle. Since the creation of a such indicator is very important for the analysis of cyclical movements of each economy, the analysis provided in this paper is conceptually based on the existing methodology of Croatian index formation (CROLEI) (Rašić Bakarić,Tkalec and Vizek, 2011), with certain modifications and construction of Serbian index SERLEl ${ }^{3}$. Also, some parts of construction of earlier version of CROLEl index is used, presented in Bačić and Vizek (2006) and in Bačić and Vizek (2008).

Frankel and Saravelos (2010) made an extensive analysis of over 80 papers which dealt with the leading indicators of business cycles. The paper suggests that the foreign exchange reserves of the central bank and currency fluctua-

\footnotetext{
${ }^{3}$ SERLEI - Serbian Leading Economic Indicator
} 
tions are variables that most consistently foresaw the crisis in the past. For the analysis of the crisis of 2008-2009 the six variables are used to measure the scope of the crisis - a drop in GDP and industrial production, currency depreciation, the performance of the stock market, the decline in foreign exchange reserves and participation in IMF programs. After econometric analysis the authors confirm what over half of the analyzed studies claimed, and that is the fact that the foreign exchange reserves in the current crisis predicted the business cycle, while the changes in exchange rates are important for explanation of the currency's weakness.

Vesselinov (2012) has designed a new leading composite index for the Bulgarian economy. To determine the turning points Bry-Boschan's method was used, a regarding time series the following six components were used: business climate in the industry, civil engineering, retail and services, employment and the Bulgarian Stock Exchange Index (SOFIX). The index indicated the movement of business cycles in Bulgaria, but as well as for each index, it takes a longer period of observations in order to determine the reliability of the index.

Literature considering leading indicators most common divide approaches in to four categories (Frankel and Saravelos, 2010, Abiad, 2003, Hawkins and Klau, 2000). Frankel and Seravelos (2010) point out „First category uses linear regression or limited dependent variable probit/logit category (Eichengreen et al., 1995, Frankel and Rose, 1996.). Second category selects number of variables as leading indicators of crisis determine thresholds values after which the indicators shows that crisis exist (Kaminsky, Lizondo and Reinhart, 1998, Bruggemann and Linne, 1999). Third category divides countries into a crisis and non-crisis control group, and then analyze the behavior of different variables during the crises (Kamin, 1988, Edwards, 1989, Edwards and Santaella,1993). Fourth category uses innovative techniques for identifying crisis, such as Markov switching models (Martinez Peria, 2002, Cerra and Chaman Saxena, 2002).“

Rašić Bakarić, Tkalec and Vizek (2011) divided methods for calculation of the leading indicators of business cycles in Croatia into a model approach, which involves identifying turning points and testing prior to business cycle using econometric modeling approach and non-modeling approach which determines the turning points using deterministic algorithms. In this context, CROLEI index calculation and the formation of the leading business cycle indicator in Serbia based on his methodology is considered a model approach. 
Kamenković S. et al.: Predicting Economic Activity In Serbia By Constructing...

\section{Materials and Methods}

CROLEl index has been created in order to timely identify business cycles turning points in Croatia. In the broadest sense, the methodology of making CROLEl index consists of four phases (Rašić Bakarić et.al, 2011) as follows:

$\mathrm{I}$ - Determining the probability of transition from the phase of recession in the phase of expansion (based on the index of industrial production)

II - Identification of macroeconomic variables whose dynamics is most intensively correlated with the time lag of GDP dynamics

III - Analysis of the correlation between the dynamics of movement of variables identified in phase II with probabilities calculated in phase I and selection of those which are most intensively correlated

IV - Calculating the value of CROLEl index based on selected economic variables from Phase II and III.

It is important to note that the gross domestic product cannot be directly used as an analytical variable because of its quarterly coverage, which significantly reduces the available time series, especially in countries such as Croatia or Serbia, where consistent time series longer than twenty years are rare, and thus reduces the ability of econometric analysis because of insufficient data. Therefore, when creating CROLEI index, the industrial production index was used, which is calculated on a monthly basis and which well reflects changes in overall economic activity (Rašić Bakarić, et al., 2011, p. 623)

Using the index of industrial production for the approximation of GDP trends is common to overcome the above mentioned disadvantages in Serbian literature as well. Zaman et al. (2011) presented methodology for recalculation of monthly GDP based on the index of industrial production. Parallel motion of deseasonalized ${ }^{4}$ index of industrial production and the change in real GDP (compared to the same quarter of the previous year), is shown in Fig. 1. Although formal correlation analysis cannot be realized because of the different time frequency of the data, visually it is clear that the index of industrial production (black curve) mostly successfully approximated the movement of GDP (grey curve) in the observed period.

\footnotetext{
${ }^{4}$ By using X-12-ARIMA method which is explained in details further in the text.

${ }^{5}$ Calculating chain measures of scale in relative prices as of 2005 which is used as a standard measure of real GDP.
} 
Figure 1 - Movement of GDP and industrial production index in Serbia in the period $2005-2011$

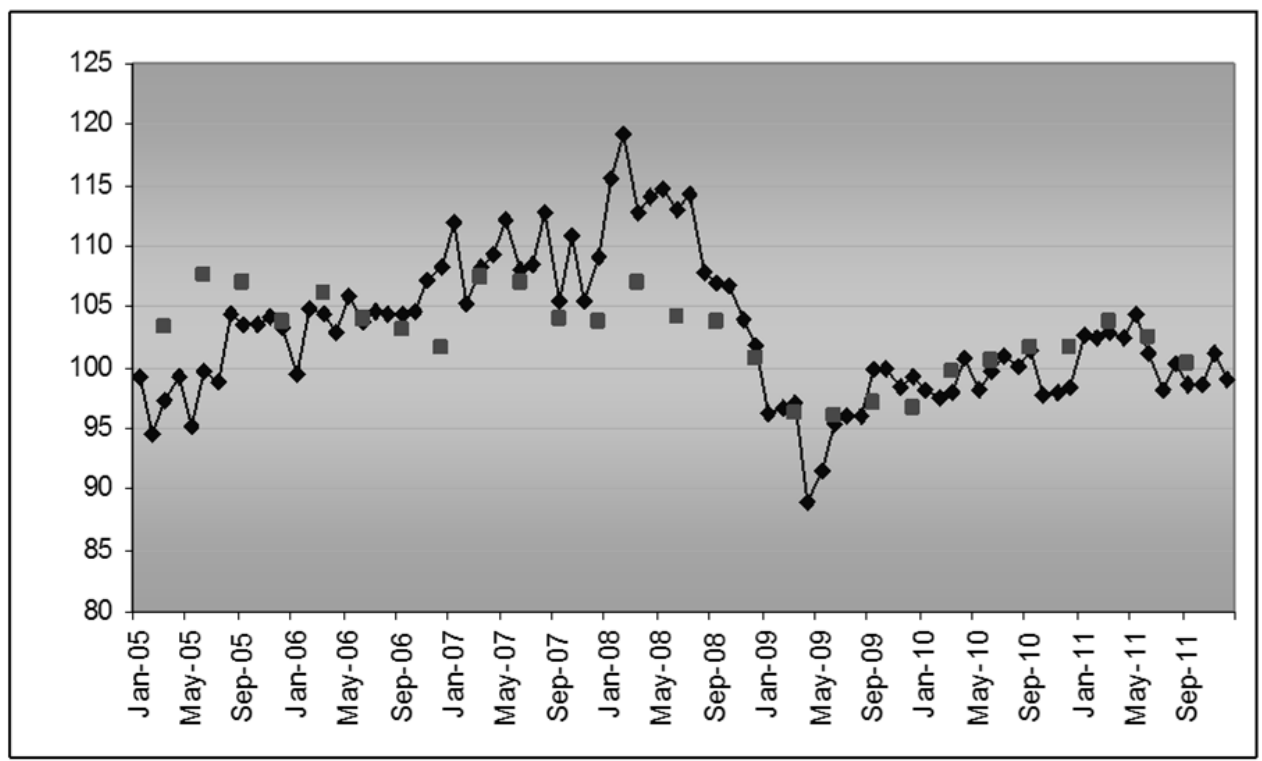

Source: Data provided by the Statistical Office of the Republic of Serbia, calculations provided by Authors

Implementation of the first phase of the business cycle indicator calculation is based on the model of Markov chains and stochastic process which characterizes the so-called "lack of memory" - the realization of the value of the stochastic process in the next moment depends only on the value of previously realized value. Formally, the random process $X_{t}$ is a Markov chain if it satisfies the following condition:

$$
P\left(X_{t+1}=x \mid X_{1}=x_{1}, \ldots, X_{t}=x_{t}\right)=P\left(X_{t+1}=x \mid X_{t}=x_{t}\right)
$$

One of the economic and mathematical models based on the properties of Markov chains frequently used in economic analysis is a Markov regimeswitching model, which was presented by Hamilton (1989) in order to model the transition from the phase of low volatility to the phase of high volatility of returns on financial assets. The idea of uni-variance of Markov regimeswitching model, used in this work, can be best illustrated by transformation of a simple autoregressive linear model given by the following formulae: 
Kamenković S. et al.: Predicting Economic Activity In Serbia By Constructing...

$$
\begin{aligned}
& \Delta X_{t}=\mu+\beta \Delta X_{t-1}+\varepsilon_{t}, \\
& \varepsilon_{t} \sim N\left(0, \sigma^{2}\right)
\end{aligned}
$$

In the following model:

$$
\begin{aligned}
& \Delta X_{t}=\mu_{S_{t}}+\beta_{S_{t}} \Delta X_{t-1}+\varepsilon_{t}, \\
& \varepsilon_{t} \sim N\left(0, \sigma_{S_{t}}^{2}\right)
\end{aligned}
$$

where $\Delta X_{t}$ is the dependent variable which regresses on its first lag, $\mu_{S_{t}}$ is a constant, $\beta_{S_{t}}$ is a regression coefficient, $\varepsilon_{t}$ is the process of "white noise" and $S_{t}$ the state of the process $\Delta X_{t}$ at time $\mathrm{t}$. In case where there are only two possible regimes of the process - economic expansion or recession, the variable $s_{t}$ is a binary variable that takes a value of 1 (expansion) or 0 (recession), and the basic model can alternatively presented by the following formulae:

$\Delta X_{t}=\mu_{1}+\beta_{1} \Delta X_{t-1}+\varepsilon_{t}, \quad \varepsilon_{t} \sim N\left(0, \sigma_{1}^{2}\right)$ the process in the regime of expansion;

$\Delta X_{t}=\mu_{2}+\beta_{2} \Delta X_{t-1}+\varepsilon_{t}, \quad \varepsilon_{t} \sim N\left(0, \sigma_{2}^{2}\right)$ the process in the regime of recession;

$P\left(S_{t}=i \mid S_{t-1}=j\right)=p_{i j}$ conditional probability of switching from one regime into another.

$S_{t}$ variable cannot be directly modeled by the regression model, and for this purpose an iterative algorithm is constructed based on maximum likelihood method. In this paper, evaluation of the model is done by using Perlin algorithm (2012) and the corresponding MATLAB program code. Results of evaluation of model parameters for the first differences in monthly deseasonalized values of the industrial production index on the sample 01/2005 - 12/2011 are shown in Table 1, with the corresponding matrix of estimated probabilities of switching from the regime of expansion into the regime of recession, as shown in Table 2: 
Table 1 - Evaluated model parameters

\begin{tabular}{|l|c|c|c|}
\hline & $\mu_{S_{t}}$ & $\beta_{S_{t}}$ & $\sigma_{S_{t}}^{2}$ \\
\hline $\begin{array}{l}\text { Expansion } \\
S_{t}=1\end{array}$ & 0.4237 & -0.3505 & 4.398259 \\
\hline $\begin{array}{l}\text { Recession } \\
S_{t}=0\end{array}$ & -0.5257 & -0.5257 & 13.74759 \\
\hline
\end{tabular}

Source: Authors' calculations

Table 2 - Switching probability matrix

\begin{tabular}{|l|c|c|}
\hline \multicolumn{1}{|c|}{$p_{i j}$} & $S_{t}=1$ & $S_{t}=0$ \\
\hline$S_{t}=1$ & 0.96 & 0.07 \\
\hline$S_{t}=0$ & 0.04 & 0.93 \\
\hline
\end{tabular}

Source: Authors' calculations

Based on the estimated model, the smoothed probabilities of switching from the regime of recession into the regime of expansion are calculated. Dynamics of these probabilities and deseasonalized index of industrial production are shown in Fig 2.

The index of industrial production (deseasonalized), shown by the grey curve whose measurement scale is given on the left ordinate, reached its peak in February 2008, and then the period of recession followed and lasted until April 2009 when it reached its minimum, after which a mild economic recovery began. Probabilities of switching from one regime into another are shown by the black curve with a measurement scale presented on the right ordinate. In literature, the realization of the switching probability at the level below/above 0.5 is treated as the identification of the business cycle shift after a time interval in which the realized values were higher / lower than 0.5 . In our case, the probability of switching indicated the commencement of the recession regime in February, 2007, that is the expansion regime in July 2009. In the context of comparative analysis of these two variables, it can be concluded that the use of Markov regime-switching model successfully announced the transition from the regime of expansion into the regime of recession. 
Kamenković S. et al.: Predicting Economic Activity In Serbia By Constructing...

Figure 2 - Probability of switching and index of industrial production in Serbia

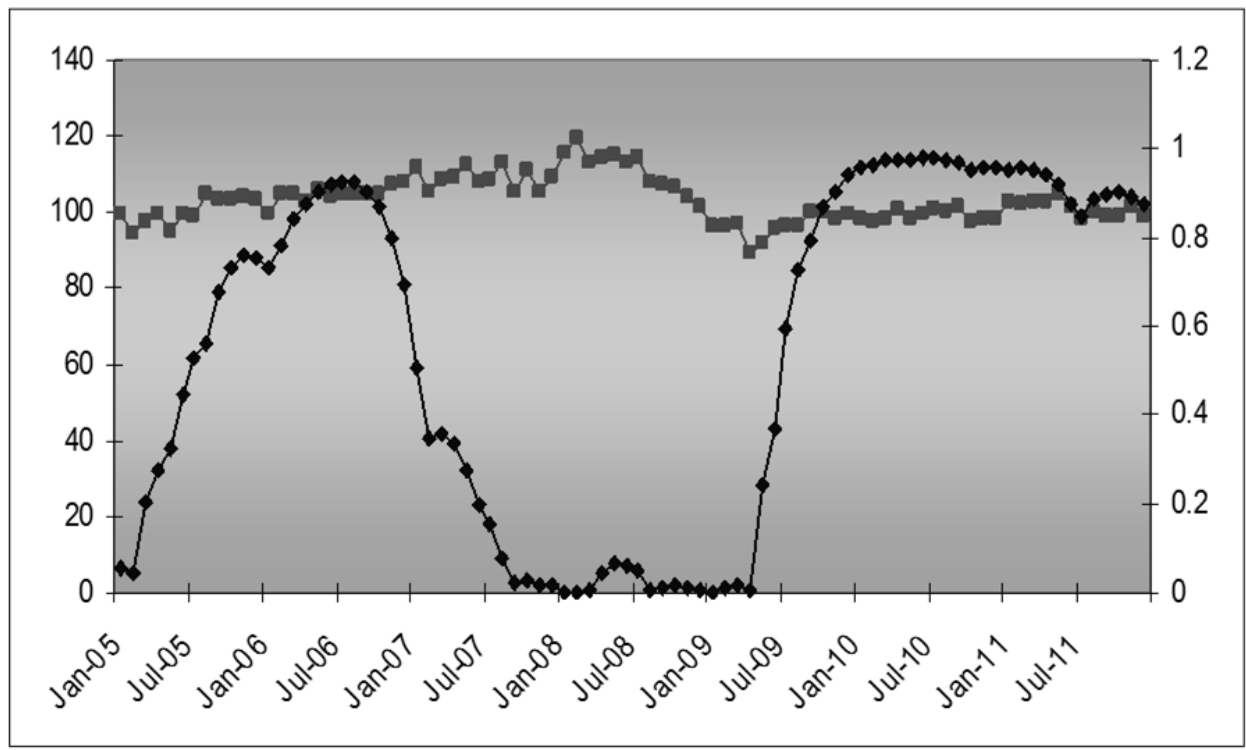

Source: Authors' calculations

In the second stage the correlation was tested between movements in the index of industrial production and time lags (the shift from one to the shift of 12 months in the past) of a great number of economic variables which represent prospective indicators of business cycle movement, that is aggregate indicator components, grouped by economic activity in the following (the number of analyzed variables is given in parentheses).

- Prices of industrial products (15)

- Consumer prices (13)

- Industrial Production (6)

- Civil Engineering (3)

- Trade, Catering and Tourism (4)

- Employment and unemployment (2)

- Salaries (2)

- Capital market (5)

- Monetary Statistics

- Fiscal statistics (13)

- International relations (6)

The selection of variables (89 in total) was largely determined by the availability of monthly data in the observed period and consistency in their measure- 
ment, as well as the need to cover as many relevant areas as possible. Therefore, the missing data are interpolated for some of the economic variables included in the analysis, the exclusion of which was estimated to greatly reduce the objectivity of research. In situations where data were available only on a quarterly basis, the cubic interpolation was used, while in situations where time series coverage was shorter than the observed period, the interpolation based on linear regression was employed.

Because of the great heterogeneity of the observed data, time series of the data having seasonal component are deseasonalized (including industrial production index) by using the X-12-ARIMA ${ }^{6}$ seasonal adjustment module incorporated in the E-views software for econometric analysis. Illustration of $\mathrm{X}$-12-ARIMA deseasonalized time series is shown in Fig 3, on the example of the index of industrial production for the period 01/2000 - 12/2011.

Figure 3 - Industrial production index in Serbia

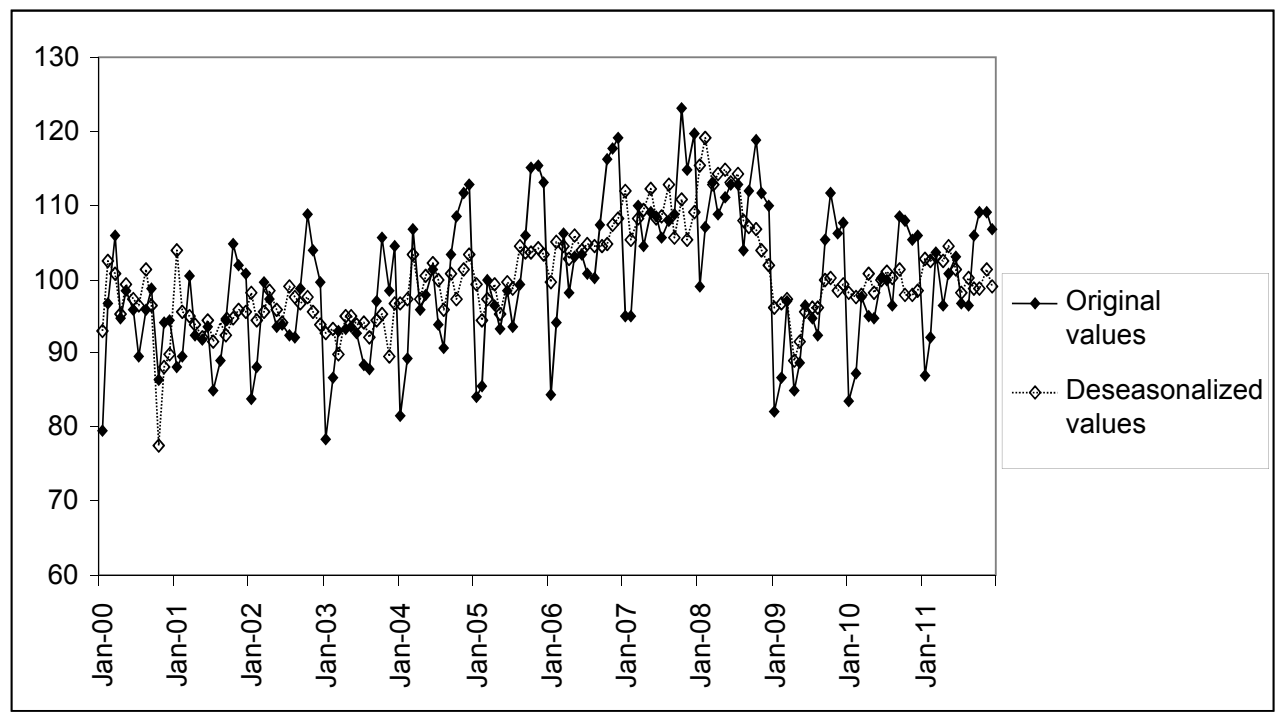

Source: Authors' calculations

Also, time series data which are monetary expressed are deflated to avoid the effects of price impact on nominal variables. The Statistical Office of the Republic of Serbia uses the consumer price index changes as the official measure of inflation, calculated since 2007. Before that the inflation was measured

\footnotetext{
${ }^{6} \mathrm{X}-12$-ARIMA is a fundamentaly special software for seasonal adjustment of time series used by the U.S.Census Bureau but it appears as a separate module within E-views program package.
} 
by using the change of retail price index which stopped to be calculated in 2010 in order to obtain a consistent time series for deflation which covers the analyzed period 2005 - 2010, we 'extended' the retail price index by using regression model. In the regression model the first derivative ${ }^{7}$ of the monthly value of the retail price index was used as the dependent variable, and as an independent variable, the first derivative of the consumer price index was used for the period 01/2007 - 12/2009. Then, based on estimated values of the regression ratio, missing values of the retail price index are projected for the years 2010 and 2011 . The correlation ratio between the values projected by the retail price index and the consumer price index was $99.6 \%$. Details of the regression analysis and projections of retail price index are given in Appendix 2.

A detailed list of the variables including the data sources and the relevant transformations shown with additional clarification is provided in Appendix 1.

Based on the correlation analysis, the variables are selected whose time lags are best correlated with the dynamics of industrial production. Given that macroeconomic variables are mostly auto-correlated, the limitation was introduced that on the quarterly shift (three time lags) for a given variable only one time lag can be selected, and the one with the highest value of correlation ratio.

In the third phase, correlation of macroeconomic variables dynamics time lag has been analyzed and probability of business cycle to be in expansion, i.e. recession. In line with CROLEI methodology, transfer probabilities assessed by a model in the phase I have been transformed by allocating every probability lower than, i.e. higher than 0.5 , value 0 , i.e. 1 . Binary time series was obtained this way suitable for a logit modeling.

Logit regression model is based on logistic function and univariant form of the model may generally be presented in the following way:

$$
\ln \left(\frac{\pi}{1-\pi}\right)=\beta_{1}+\beta_{2} X+\varepsilon, \varepsilon \sim N\left(0, \sigma^{2}\right),
$$

where $\pi$ represents probability that an observed event (expansion) took place, and $X$ an independent variable on the basis of which realization probabilities pertaining to the observed event are being modeled. Since there are no analytic solutions for regression coefficient assessments, they could only be assessed by numeric optimization methods, on the basis of maximal credibility models. Regression coefficients in this paper have been assessed by

\footnotetext{
${ }^{7}$ Instead of original values, in order to obtain 'better; statistical features of the evaluated residual values.
} 
Newton-Raphson numeric optimization model in MS Excel, on the basis of the program VBA (Visual Basic for Application) designed for this purpose.

Table 3, Logit p2 column, shows p-values for selected variables on the basis of correlation analysis and t-statistics of assessed logit regression coefficient reflecting statistic importance of regression relation with transformed probabilities.

In the last phase, on the basis of crossing analyses from phase II and phase III, 16 variables have been selected with best characteristics in the context of anticipating future trends in industrial production index moving, i.e. GDP. Pursuant to these variables, i.e. their time lags, an indicator has been designed for predicting business cycles turns. Four criteria have been used on the selection process:

- $\quad$ Time lag criterion - correlations have been eliminated at the first, second and third time lag. Having in mind that economic policy effects require certain time progress, as well as that there is certain delay in measuring and reporting for certain variables comprised by this analysis, it has been assessed that correlation should not be taken into consideration for such small time progresses.

- $\quad$ Logit p-value criterion - correlation with logit p-values higher than 0.01 have been eliminated, i.e. where hypothesis on non-existence of statistically important logit regression link cannot be rejected with an error risk below $1 \%$.

- 'Outlier' elimination criterion - variables with a huge number of extreme values have been eliminated despite their desirable regression features due to excessive influence on designed (constructed) indicator's values (e.g., turnover at the Belgrade Stock Exchange).

- $\quad$ One variable criterion - in case there are more time lags of the same variable left following application of all previously mentioned in selection (in our case, the Belgrade Stock Exchange index values and wood processing), ones belonging to time progress of 7-9 time lags have been selected, respecting the greater correlation (which has declined in time for most variables) on one hand, and the greater time progress possible (so that business cycles dynamics is identified in a timely manner).

Application of these selection criteria resulted in a list of 16 variables from the initial list of 70 correlations, on the basis of which SERLEI indicator has been designed. List of variables is presented in the Table 3 below. 
Kamenković S. et al.: Predicting Economic Activity In Serbia By Constructing...

Table 3 - List of variables included in SERLEl indicator design

\begin{tabular}{|l|l|l|l|}
\hline \multicolumn{1}{|c|}{ Variable } & Time lag & Correlation & Logit $\mathrm{p} 2$ \\
\hline $\begin{array}{l}\text { Processing industry - industrial produc- } \\
\text { tion index }\end{array}$ & $\mathrm{t}-4$ & 0.718732 & 0.000221 \\
\hline $\begin{array}{l}\text { Processing industry - manufacturers' } \\
\text { price index }\end{array}$ & $\mathrm{t}-4$ & 0.715902 & 0.000215 \\
\hline $\begin{array}{l}\text { Rubber and plastic production - manu- } \\
\text { facturers' price index }\end{array}$ & $\mathrm{t}-4$ & 0.502260 & 0.000337 \\
\hline Belex15 level & $\mathrm{t}-7$ & 0.681071 & 0.000078 \\
\hline Belexline level & $\mathrm{t}-7$ & 0.670285 & 0.000062 \\
\hline Industrial production index, total & $\mathrm{t}-4$ & 0.664397 & 0.000481 \\
\hline Import VAT & $\mathrm{t}-4$ & 0.597082 & 0.000170 \\
\hline $\begin{array}{l}\text { Effective working hours in civil engineer- } \\
\text { ing }\end{array}$ & $\mathrm{t}-4$ & 0.572544 & 0.000088 \\
\hline $\begin{array}{l}\text { Wood processing and wood products - } \\
\text { manufacturers' price index }\end{array}$ & $\mathrm{t}-7$ & 0.568944 & 0.000171 \\
\hline $\begin{array}{l}\text { Non-durable consumer products - manu- } \\
\text { facturers' price index }\end{array}$ & $\mathrm{t}-4$ & 0.552989 & 0.000068 \\
\hline Excise & $\mathrm{t}-4$ & 0.540298 & 0.000017 \\
\hline Avista deposits & $\mathrm{t}-4$ & 0.502260 & 0.000017 \\
\hline $\begin{array}{l}\text { Beverage production - manufacturer's } \\
\text { price index }\end{array}$ & $\mathrm{t}-4$ & 0.502260 & 0.000224 \\
\hline $\begin{array}{l}\text { Food industry - industrial production in- } \\
\text { dex }\end{array}$ & $\mathrm{t}-4$ & 0.521218 & 0.000143 \\
\hline $\begin{array}{l}\text { Banking sector consolidated balance - } \\
\text { total loans }\end{array}$ & $\mathrm{t}-12$ & -0.516515 & 0.004947 \\
\hline M2 & $\mathrm{t}-12$ & -0.514282 & 0.001473 \\
\hline
\end{tabular}

Source: Author's calculations

\section{Results and discussion}

The ultimate indicator was designed according to the following algorithm firstly, all variables were normalized in contrast to their minimal value in series so that measuring scale of such heterogeneous group of variables was unified. Normalized values of variables at relevant time lags were then weighted (equal weighting, weight equals 1/16) and summed so that aggregated indicator was obtained. Parallel dynamics of this indicator and industrial production index movements (logarithm values) are presented in Fig 4. 
Kamenković S. et al.: Predicting Economic Activity In Serbia By Constructing ...

Figure 4 - Movement of Serbia's business cycle indicator, SERLEI

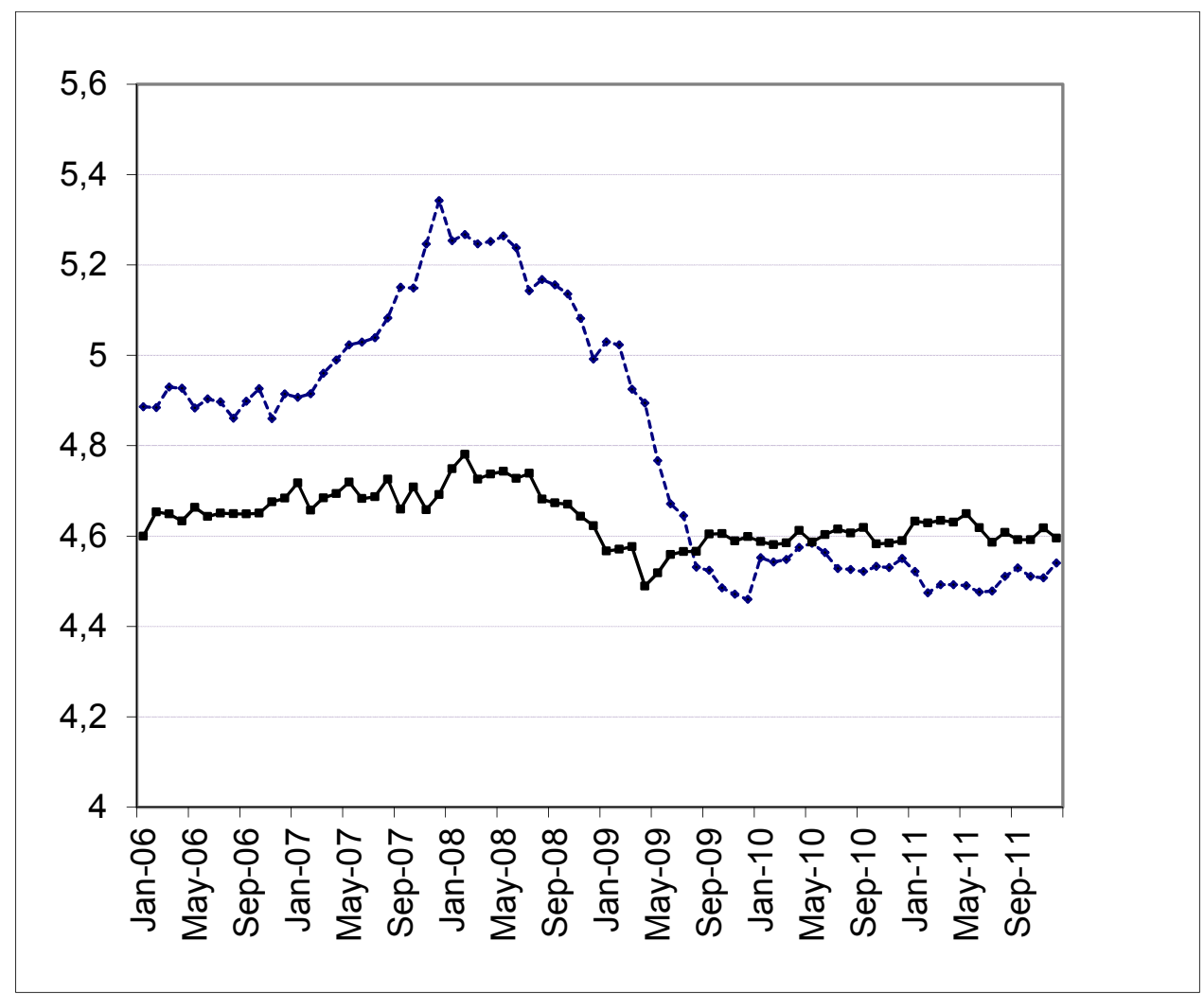

Source: Author's calculations

The figure above shows that business cycles indicator designed in line with previous methodology has demonstrated extreme sensitivity to changes in economic movements in the period from 2007 - 2009, and announced first expansion by its sharp increase, followed by recession by its sharp fall. Indicator reached its peak in this period, in December, 2007, two months before deseasoned industrial production index reached its maximum, which is in full compliance with index CROLEI results presented in Fig 5, pertaining to time indication.

One should note that 8 variables were used when designing leading business cycles index in Croatia. They were mainly different from time series included in creation of leading business cycles indicator in Serbia. Appendix 3 shows comparative review. Taking numbered selection criteria for indicator's components into consideration, differences could be explained by differences in Ser- 
Kamenković S. et al.: Predicting Economic Activity In Serbia By Constructing...

bian, in contrast to Croatian economy. Availability of data has also been an additional hindering factor.

Figure 5 - Movement of CROLEI index in the period from $1998-2010$

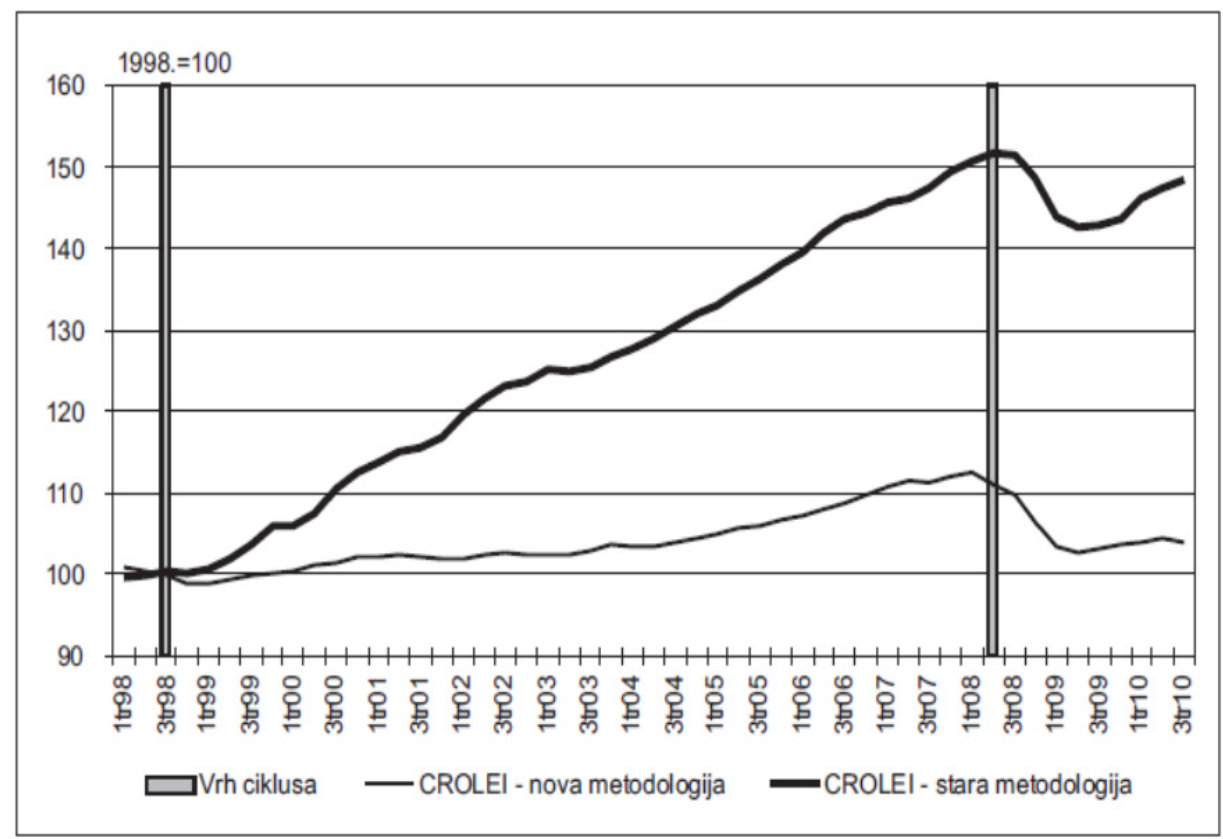

Source: Bakarić, Tkalec and Vizek (2011, pg. 632)

One should note that created indicator failed to reiterated economic recovery in timely manner, industrial production index dynamics indicated in mid-2009. However, comparative review of industrial production index and GDP changes presented in Fig 1 shows there was no economic expansion, but only that the level of industrial production balanced after a short decline in the beginning of 2009 and that the period of mild expansion took place in the beginning of 2012, which is in line with the designed indicator dynamics.

\section{Conclusion}

Application of described methodology has created an indicator that comprehensively follows economic movements in Serbia and in timely manner points at changes in trends, besides a number of limitations authors have encoun- 
tered, in availability of data above all. Business cycles indicator SERLEI created by previous methodology has demonstrated an extreme sensitivity to changes in economic movements in the period from 2007 - 2009. It suggested expansion in the very beginning by a sharp increase, and then a recession by a sharp decline. Indicator reached its peak in this period in December, 2007, two months before deseasoned industrial production index reached its maximum. Two months is time progress, leading indicator created this way, offers to economic policy stakeholders for preparation of adequate measures, which could be precious time in certain, and particularly crisis circumstances. SERLEI has still not announced end of the crisis for the economy, just a mild recovery with balanced economic activity following the crisis period.

Unlike CROLEI index based on analysis of even 278 economic variables, for design of SERLEI index, only 89 was used since we were not able to find out monthly data on many macroeconomic variables ${ }^{8}$ than are not available to the public or could be provided only by means of financial compensation to institutions that primarily create them. In this context, results of this analysis could be described as ultimately satisfactory. A suggestion for economic policy makers in Serbia could be that it would be very useful to create such an indicator and thus take a more serious approach to the timely identification of business cycles issue and accordingly timely passing of relevant economic policy measure, having in mind better access to data, as well as more significant research and financial capacities than those at disposal of the authors themselves.

\section{References}

Abiad, A. (2003). Early Warning Systems: A Survey and a Regime-Switching Approach. In IMF Working Papers. International Monetary Fund. 03.

Bačić, K., \& Vizek, M. (2006). A Brand New CROLEI - Do we need a new forecasting index. Financijska teorija i praksa, 30(4), 311-346.

Bačić, K., \& Vizek, M. (2008). Forecasting business and growth cycles in Croatia. Ekonomski pregled, 50(11), 646-668.

- Belgrade Stock Exchange Retrieved from www.belex.rs

Brüggemann, A., \& Linne, T. (1999). How Good are Leading Indicators for Currency and Banking Crises in Central and Eastern Europe?, An Empirical Test. In IWH Discussion Papers. Halle Institute for Economic Research.

Cerra, V., \& Saxena, C.S. (2002). Contagion, Monsoons, and Domestic Turmoil in Indonesia's Currency Crisis. Review of International Economics, 10, 36-44.

Edwards, S. (1989). Real Exchange Rates, Devalution, and Adjustmen: Exchange Rate Policy in Developing Countries. Cambridge, MA: MIT Press.

\footnotetext{
${ }^{8}$ For example, we did not have disaggregated data on salaries and employments by sectors, import and export structure, foreign direct investments, etc.
} 
Kamenković S. et al.: Predicting Economic Activity In Serbia By Constructing...

Edwards, S., \& Santaella, J. (1993). Devaluation Controversies in the Developing Countries; Lessons from the Bretton Woods Era. In A retrospective on the Bretton Woods System: Lessons for International Monetary Reform. (pp. 405-460). NBER.

Eichengreen, B., Rose, A.K., \& Wyplosz, C. (1995). Exchange rate mayhem: The antecedents and aftermath of speculative attacks. Economic Policy, 10(21), 249312.

Frenkel, J.A., \& Rose, A. (1996). Currency Crashes in Emerging Markets: An Empirical Treatment. Journal of International Economics, 41(3-4), 351-366.

Frankel, J. A. and Saravelos G. (2010). Are Leading Indicators of Financial Crises Useful for Assessing Country Vulnerability? Evidence from the 2008-09 Global Crisis. NBER Working Papers 16047, National Bureau of Economic Research, Inc.

- Fund for Development of Economics Retrieved from www.fren.org.rs

Hamilton, J.D. (1989). A New Approach to the Economic Analysis of Nonstationary Time Series and the Business Cycle. Econometrica, 57(2), 357-384. doi:10.2307/1912559

Hawkins, J., \& Klau, M. (2000). Measuring potential vulnerabilities in emerging market economies. In BIS Working Papers. Basle: Bank for International Settlements.

Kamin, S.B. (1988). Devaluation, External Balance and Macroeconomic Performance a Look at the Numbers. InPrinceton Studies in International Economics. Princeton: International Economic Section, Department of Economics Princeton University.

Kaminsky, G.L., Lizondo, S., \& Reinhart, C.M. (1998). Leading indicators of currency crisis. IMF Staff Papers, Washington, 45(1), 1-48.

Peria, M.M. (2002). A Regime - Switching Approach to the Study of Speculative Attack: A Focus on EMS Crisis.Empirical Economics, 27(2), 299-334.

- National Bank of Serbia Retrieved from www.nbs.rs

Praščević, A. (2009). Ekonomska politika Srbije između svetske ekonomske krize i predizbornih obećanja. InEkonomska politika Srbije u 2009.godini: Izazovi svetske ekonomske krize. Beograd: Ekonomski fakultet i Naučno društvo ekonomista.

Rašić, B.I., Tkalec, M., \& Vizek, M. (2011). Primjena modelskog pristupa izračunu navješćujućeg kompozitnog indeksa: slučaj CROLEl indeksa. Ekonomski pregled, 62(11), 613-635.

- Statistical Office of the Republic of Serbia (2007) Retrieved from www.stat.gov.rs

Vesselinov, R. (2012). New Composite Indicators for Bulgarian Business Cycle. International Journal of Economic Sciences and Applied Research, 5(2), 101-111. Retrieved from http://ssrn.com/abstract=2155592

Zaman, , \& et al., (2011). Ekonometrijska procena i projekcija mesečnih budžetskih prihoda. In Priručnik za analizu javnih finansija. (pp. 69-70). 


\section{Appendices}

\section{Appendix 1 - The list of variables used in correlation analysis and logit regression}

The list comprises names of the variables and data sources, as well as the notes on time series transformations in order to eliminate seasonal components and inflation, i.e. interpolations of the missing data in the following symbols:

- ds - desessonized

- $\quad$ def - deflationary

- int - interpolated

All data are available to the public, apart from those referring to the revenue side of the state budget and which are directly provided by the Ministry of Finance, IT Sector.

\section{Industrial products prices (15) base index}

Indices of the producers of industrial products for domestic market grouped by the purpose:

1. Energy (ds)

2. Intermediary products, apart from energy (ds)

3. Capital products (ds)

4. Durable commodities (ds)

5. Non-durable commodities (ds)

Price indices of industrial products for domestic market by KD 2010:

1. $\quad$ Mining (ds)

2. Processing industry (ds)

3. Production of beverages (ds)

4. Tobacco production (ds)

5. Textile production (ds)

6. Wood processing and wood products, cork, straw and spur, apart from furniture (ds)

7. Coke production and oil derivatives (ds)

8. Production of rubber and plastic products (ds)

9. Base metals products (ds)

10. Electricity supply, gas and steam supply and air-conditioning (ds)

Source: Data base by the Statistical Office of the Republic of Serbia

\section{Consumer prices (13)}

Consumer price indices, base $(2006=100)$

1. Food and beverages (int)

2. Spirits, tobacco and narcotics (int)

3. Real living rents (int)

4. Electricity, gas and other fuels (int)

5. Drugs (int)

6. Medical services (int)

7. Transport (int)

8. Communications (int)

9. Recreation and culture (int)

10. Education (int)

11. Restaurants and hotels (int)

12. Insurance (int)

13. Financial services (int)

Given that the consumer price index has been calculated yet as of 2007, the missing values of the consumer price indices included in the analysis for the period 01/2005-12/2006 are interpolated on the basis of linear regression of these variables for the period 01/2007 - 12/2009, where 
as regressors time series of retail price index were used (base, 2005) whose calculation was stopped as of 2009 , for the following group of products:

- Goods;

- $\quad$ Agricultural produces;

- Industrial products;

- Industrial food produces;

- Beverages;

- Tobacco;

- Industrial non-food products;

- Services.

Corrected ration of determination of each of these regressions was higher than $90 \%$.

Source: Data base by the Statistical Office of the Republic of Serbia

3. Industrial production (6)

Industrial production index by the field of activity:

1. Total (ds)

2. Electricity (ds)

3. Coke and oil (ds)

4. Base metals (ds)

5. Food industry (ds)

6. Processing industry (ds)

Source: Data base by the Statistical Office of the Republic of Serbia

\section{Civil Engineering (3)} base $2011=100$

1. Effective labour hours in civil engineering (int, ds)

2. Value of the performed civil engineering work (int, ds)

3. Number of finished apartments (int, ds)

All-time series included in the analysis which refer to civil engineering are originally of a quarter coverage. The missing monthly data are generated by cubic interpolation.

Source: Statistics by the National Bank of Serbia

\section{Trade, catering and tourism (4)}

1. Retail sale index $(2011=100)$, permanent prices (ds)

2. Catering turnover index $(2011=100)$, permanent prices (ds)

3. Number of tourists (ds)

4. Number of over-night stays (ds)

Source: Statistics by the National Bank of Serbia

\section{Employment and unemployment (2)}

1. Total number of the employed

2. Total number of the unemployed

Source: Statistics by the National Bank of Serbia

\section{Salaries (2)}

1. Average gross salary (ds, def)

2. Average net salary (ds, def)

Source: Statistics by the National Bank of Serbia

\section{Capital market (5)}
1. Belex15 level (int)
2. Belex15 turnover (int, def)
3. Belexline level
4. Belexline turnover (def)
5. Belexsentiment (int) 
The missing values for Belex 15 index (level and turnover) which is being calculated since October 2005 are interpolated on the basis of the linear regression, where the level and turnover of Belexline are used as regressors. The missing values for Belex sentiment ( - May 2005) are interpolated based on the average monthly growth rate of the value of this indicator for the period for which the data are available, given that it was not determined that this variable was correlated with some other capital market indicator, and the cubic interpolation have not provided a successful fitting.

Source: Belgrade Stock Exchange

\section{Monetary statistics (23)}

1. $\mathrm{M} 1$ (def)

2. M2 (def)

3. M3 (def)

4. Cash in circulation (def)

5. Deposits by sight (def)

6. Dinar currency primary money (def)

7. Total primary money (def)

8. Bank reserves in dinars at NBS (def)

9. Term deposits in dinar currency (def)

10. Short-term savings in dinar currency (def)

11. Long-term savings in dinar currency (def)

12. Total savings in dinar currency (def)

13. Short-term savings in foreign currency (def)

14. Long-term savings in foreign currency (def)

15. Total savings in foreign currency (def)

16. Total savings (def)

17. Consolidated balance of banking sector assets - domestic (def)

18. Consolidated balance of banking sector assets - foreign (def)

19. Consolidated balance of banking sector assets - total loans (def)

20. Consolidated balance of banking sector assets - total assets (def)

21. Consolidated balance of banking sector liabilities - liabilities abroad (def)

22. The weighted average interest rate on the securities held by the National Bank of Serbia for operations on the open market

23. The weighted average interest rate on treasury bonds of the Republic of Serbia in dinar currency

Source: Statistics by the National Bank of Serbia

\section{Fiscal statistics (13)}

1. Public income (def)

2. Withholding tax (ds, def)

3. Corporate tax (ds, def)

4. Value Added Tax in the country (ds, def)

5. Value Added Tax on imports (ds, def)

6. Excise (def)

7. Customs (ds, def)

8. Non-tax income

9. Privatization (def)

10. Public expenditures (int, ds, def)

11. Employment expenses (int, ds, def)

12. Subsistence allowance and transfers (int, ds, def)

13. Pensions (int, def)

Time series of the variables from the revenue side of the public finances refer to the state budget. Time series of the variables from the expenditure side of the public finances refer to consolidated balance of the state and are calculated on the basis of cubic interpolation of the quarterly data. 
Kamenković S. et al.: Predicting Economic Activity In Serbia By Constructing...

Source: Data base of the Ministry of Finance of $\mathrm{RS}^{9}$, Data base of the Fund for Development of Economics

\section{International relations (6)}

1. Imports (ds, def)

2. Exports (ds, def)

3. Real foreign currency exchange rate RSD/EUR (def)

4. Real foreign currency exchange rate RSD/USD (def)

5. Real foreign currency exchange rate RSD/CHF (def)

6. Foreign currency reserves (def)

Original data on foreign exchange reserves denominated in euros are converted into dinars

based on monthly exchange rates available on the website of the National Bank of Serbia.

Source: Statistics by National Bank of Serbia

\section{Appendix 2 - Interpolation of the retail price index}

By linear regression of the first differentiation of the retail price index to the consumer price index for the period 01/2007 - 12/2009 the following results were obtained:

\begin{tabular}{|l|l|}
\hline \multicolumn{2}{|l|}{ Regression Statistics } \\
\hline Multiple R & 0.804320127 \\
\hline R Square & 0.646930866 \\
\hline Adjusted R Square & 0.636231802 \\
\hline Standard Error & 0.59025786 \\
\hline Observations & 35 \\
\hline
\end{tabular}

\begin{tabular}{|l|l|l|l|l|}
\hline & Coefficients & Standard Error & $t$ Stat & $P$-value \\
\hline Intercept & 0.367500927 & 0.12554 & 2.927367 & 0.006149 \\
\hline X Variable 1 & 0.725086278 & 0.093247 & 7.775996 & $5.85 \mathrm{E}-09$ \\
\hline
\end{tabular}

Interpolated missing values of the retail price index and the consumer price index, which were used as regressors are shown in the table below:

\begin{tabular}{|l|l|l|}
\hline \multicolumn{1}{|c|}{ Date } & Retail price index & Consumer price index \\
\hline 2010/January & 149.3 & 131.4 \\
\hline 2010/February & 150.0 & 131.8 \\
\hline 2010/March & 151.5 & 133.4 \\
\hline 2010/April & 152.4 & 134.1 \\
\hline 2010/May & 154.2 & 136.1 \\
\hline 2010/June & 155.0 & 136.7 \\
\hline 2010/July & 155.3 & 136.6 \\
\hline 2010/August & 157.0 & 138.5 \\
\hline 2010/September & 158.7 & 140.3 \\
\hline 2010/October & 160.1 & 141.7 \\
\hline 2010/November & 161.9 & 143.7 \\
\hline 2010/December & 162.6 & 144.2 \\
\hline 2011/January & 164.4 & 146.2 \\
\hline 2011/February & 166.3 & 148.3 \\
\hline 2011/March & 169.5 & 152.2 \\
\hline
\end{tabular}

\footnotetext{
${ }^{9}$ www.mfin.gov.rs
} 


\begin{tabular}{|l|l|l|}
\hline $2011 /$ April & 171.1 & 153.8 \\
\hline $2011 /$ May & 171.9 & 154.4 \\
\hline $2011 /$ June & 171.9 & 154.0 \\
\hline $2011 /$ July & 171.7 & 153.2 \\
\hline $2011 /$ August & 172.0 & 153.1 \\
\hline $2011 /$ September & 172.5 & 153.3 \\
\hline $2011 /$ October & 173.4 & 154.0 \\
\hline $2011 /$ November & 174.7 & 155.3 \\
\hline $2011 /$ December & 174.4 & 154.3 \\
\hline $2012 /$ January & 174.8 & 154.4 \\
\hline $2012 /$ February & 176.1 & 155.7 \\
\hline $2012 /$ March & 177.7 & 157.4 \\
\hline $2012 /$ April & 178.7 & 158.3 \\
\hline
\end{tabular}

Correlation ratio between projected values of the retail price index and consumer price index totals $99.6 \%$.

\section{Appendix 3 - Comparative review of the indicator components in Croatia and Serbia}

Time series - Croatian index components:

1. Average gross salary in the sector of coke production and refined oil products

2. Production volume index of other non-metal mineral products

3. Machinery and transport devices imports

4. Production volume index in the processing industry in the EU 15

5. New orders index in the processing industry in the EU

6. CROBEX index

7. The difference between interest rates on long-term loans with foreign currency clause to companies and term deposits in euros

8. State budget revenues from taxes on international trade and transactions (customs revenue)

Time series - Serbian index components:

1. Processing industry - industrial production index

2. Processing industry - producer price index

3. Production of rubber and plastic products - producer price index

4. Belex15 level

5. Belexline level

6. Industrial production index - total

7. Value Added Tax on Imports

8. Effective labour hours in civil engineering

9. Wood processing and wood products, cork, straw and spur, apart from furniture - producer price index

10. Non-durable commodities -producer price index

11. Excise

12. Deposits by sight

13. Production of beverages - producer price index

14. Food processing industry - industrial production index

15. Consolidated balance of banking sector assets - total loans

16. Money mass M2 